ANADOLU, J. of AARI

ISSN: 1300-0225 (Print)

E-ISSN: 2667-6087 (Online)

2021, 31 (1): 9-20

DOI: $10.18615 /$ anadolu.949833

\title{
Water-Yield Relations of Drip Irrigated Maize in Arid and Semi-Arid Regions
}

\author{
Süheyla KARA ${ }^{1}$ (D) Mehmet SAHIN ${ }^{2 *}$ \\ ${ }^{1}$ Provincial Directorate of Agriculture and Forestry, Konya/TURKEY \\ ${ }^{2}$ Selcuk University, Agricultural Faculty, Dept. of Agricultural Structures and Irrigation, Konya/TURKEY \\ ${ }^{l}$ https://orcid.org/0000-0001-6114-3345 $\quad{ }^{2}$ https://orcid.org/0000-0001-5989-7092 \\ ${ }^{*}$ Corresponding author's (Sorumlu yazar) e-mail: mhsahin@selcuk.edu.tr \\ Received (Geliş tarihi): 03.07.2020Ａccepted (Kabul tarihi): 07.10.2020
}

ABSTRACT: This study was conducted to determine water-yield relations of drip-irrigated maize that was grown in Central Anatolia Region of Turkey with a dominant arid and semi-arid climate. Four different irrigation treatments were applied to experimental plots in 7-day intervals. Irrigation treatments were laid out based on 7-day cumulative evaporation from class- $A$ pan $\left(I_{120}-120 \%, I_{100}-100 \%, I_{80}-80 \%\right.$ and $I_{60}-60 \%$ of pan evaporation). Applied irrigation water quantities varied between 431-676 mm in 2009 and between 453-726 $\mathrm{mm}$ in 2010. The greatest seasonal water consumption (821 mm) was observed in $\mathrm{I}_{120}$ treatment of 2010 and the lowest $(590.1 \mathrm{~mm})$ in I60 treatment of 2009. The greatest kernel yield per hectare $\left(15773 \mathrm{~kg} \mathrm{ha^{-1 } )}\right.$ was obtained from II20 treatment of 2010 and the lowest $\left(8986 \mathrm{~kg} \mathrm{ha}^{-1}\right.$ ) from I60 treatment of 2009. Water use efficiency (WUE) values varied between 1.45-1.99 $\mathrm{kg} \mathrm{m}^{-3}$ and irrigation water use efficiency (IWUE) values varied between 1.84-2.39 $\mathrm{kg} \mathrm{m}^{-3}$. Yieldresponse factor (ky) of maize was calculated as 1.47 in 2009 and 1.36, in 2010. While I100 was recommended as the ideal irrigation program, I80 treatments could also be used to improve water use efficiencies in places where full irrigation is not possible.

Keywords: Corn, Zea mays L., seed yield, class-A pan, drip irrigation, water use efficiencies.

\section{Kurak ve Yarı Kurak Bölgelerde Damla Sulama ile Sulanan Mısır Bitkisinin Su-Verim İlişsileri}

ÖZ: Bu araștırma, Türkiye'nin kurak ve yarı kurak iklim özelliği gösteren Iç̧ Anadolu Bölgesi'nde yer alan Konya ilinde damla sulama yöntemi ile sulanan mısır bitkisinin su-verim ilişkilerini belirlemek amacıyla yürütülmüş̧ür. Araştırmada, parsellere 7 gün sulama aralı̆̆ında dört farklı sulama miktarı uygulanmıştır. Sulama suyu miktarları, A sınıf buharlaşma kabından oluşan ylğışımlı buharlaşma değerinin; \% 120'si (II20), \% 100'ü (I I00), \% 80'i (I80) ve \% 60'l (I60) alınarak oluşturulmuştur. Araştırmada konulara 2009 yılında 431-676 mm, 2010 yılında ise 453-726 mm arasında değişen miktarlarda su uygulanmıştır. Araştırma sonuçlarına göre, misır bitkisinin mevsimlik su tüketimi en yüksek $821 \mathrm{~mm}$ ile 2010 yllında $I_{120}$ konusunda, en düşük $590.1 \mathrm{~mm}$ ile 2009 yllında Ito konusunda gerçekleşmiştir. Birim alan tane verimi, en yüksek $15773 \mathrm{~kg} \mathrm{ha-1}$ ile 2010 yılında II20 konusunda; en düsük ise $8986 \mathrm{~kg} \mathrm{ha}{ }^{-1}$ ile 2009 yılında I60 konusundan elde edilmistir. Su kullanım randımanı (WUE) ve sulama suyu kullanım randıman (IWUE) konulara bağlı olarak, sirastyla $1.45-1.99 \mathrm{~kg} \mathrm{~m}^{-3} \mathrm{ve} 1.84-2.39 \mathrm{~kg} \mathrm{~m} \mathrm{~m}^{-3}$ arasında değișmiștir. Misır verim tepki etmeni (ky) 2009-2010 yıllarında sırası ile 1.47 ve 1.36 olarak hesaplanmıștır. Araștırma sonucunda Iıo konusu ideal sulama programı olarak önerilirken, tam sulamanın mümkün olmadı̆̆ koşullarda mevcut su potansiyeline bağlı olarak I $I_{80}$ konusu da benzer ekolojik bölgelerde su kullanım verimliliğini artırmak için önerilebilir.

Anahtar Kelimeler: Mısır, Zea mays L., verim, A sınıfi buharlaşma kabı, damla sulama, su kullanım etkinliği. 


\section{INTRODUCTION}

Among cereal crops, maize is perfectly rich in nutrients, thus playing a significant role in human nutrition and animal feed. With a rich starch and oil content, maize is also used as a raw material in the starch-based sugar and oil industries. Cereals compensate for the nutritional needs of the everincreasing world and Turkish population. The USA (36\%) is the leading maize producer of the world and China $(21 \%)$ is the second greatest maize producer. Kernel maize production is performed over 189 million ha worldwide and annual grainkernel production is around 1.088 million tons (Anonymous, 2017). In 2018, in Turkey, kernel maize production was practiced over 591.900 ha and annual production was 5.7 million tons. In Konya province, maize is cultivated on over 107.462 ha and annual production was 110.453 tons (Anonymous, 2018). In this region, maize was cultivated on only 13.138 ha in 2009 ; thus, by 2018 , this value increased by $718 \%$. The primary reason for such a great increase in cultivated area is the greater income-generating potential of maize for farmers compared to other cereals. Widespread use of drip irrigation in the region also accelerated the rate of increase in land used for maize cultivation.

Konya province has a dominant terrestrial climate with hot-dry summers and quite limited water resources. Annual precipitation levels are below $350 \mathrm{~mm}$. Both limited water resources and quite low precipitation levels obligate efficient water use for irrigation. Irrigation is a vital component of agricultural practices especially in Konya province. As compared to other cereal crops, maize has a relatively greater irrigation water requirement (Van Donk et al., 2013). Despite the limited water resources of the region, the rapidly increasing area of land under maize cultivation entailed the development of new irrigation techniques and programs. In the near future, the primary challenge will be more productions with less water. Therefore, in such regions, pressurized irrigation methods should be widespread to improve water use efficiencies. Optimum plant growth could be achieved by applying sufficient quantities of water at proper times in a suitable agroecological zone. Previous studies revealed that kernel yield per hectare could be significantly increased with accurate irrigation schedules (Çakır, 2004; Kızıloğlu et al., 2008; Kara and Biber, 2008). Field irrigation losses constitute the greatest losses in agricultural irrigation. Such losses are reduced by selection of appropriate programs and management practices pursuant to soil-plant-water relations. Drip irrigation with a high water application efficiency should be preferred in regions with deficit water resources. The drip irrigation method has various advantages over the other pressurized irrigation methods in terms of plant and nutrient management, saline water management, yield and quality, disease and pests control, weed control and deep percolation (Doğan and Kurnak, 2010). Maize culture has been practiced under drip irrigation in Konya region and the method is also supported by the Turkish Government.

Deficit irrigation is a strategy for efficient water use in irrigation. It improves water and irrigation water use efficiencies of irrigation. In deficit irrigation, plants are exposed to specified water stress levels at certain growth stages of varying times up to harvest. In this way, water saving is provided without significant yield losses (Kırda, 2002). Water-yield relations should be well comprehended while generating deficit irrigation programs and deficits should then be shaped accordingly. Some previous researchers reported linear decreases in yields with decreasing crop water consumption and indicated such a relation as a yield response factor (ky) (Stewart et al., 1976; Doorenbos and Kassam, 1979; Yazar et al., 2002).

Crop evapotranspiration is mostly estimated from correlations between evaporation measured from class-A pans and reference crop evapotranspiration. Since the climate factors effective on pan evaporations are also effective on crop water consumption, quite accurate results are achieved with this method. This method of 
estimation is commonly used worldwide (Irmak et al., 2002; Kızıloğlu et al., 2008).

The present research was carried out to assess water consumption, yield response factor (ky) and water use efficiency of drip-irrigated maize cultivated in Konya province located in the Central Anatolia Region of Turkey with dominant terrestrial climate.

\section{MATERIALS and METHODS}

"Market" hybrid grain corn cultivar was used as an experimental material. Market is a medium maturity hybrid maize in FAO 600 group, resistant to common smut (Ustilago maydis) and Fusarium graminearum. The experiment was conducted on experimental fields of Konya Sugar Company in 2009 and 2010 growing seasons. The experimental fields are located between $36^{\circ} 42^{\prime}-39^{\circ} 16^{\prime} \mathrm{N}$ latitudes and $31^{\circ} 14^{\prime}-34^{\circ} 26^{\prime} \mathrm{E}$ longitudes. The altitude of the experimental site is $1020 \mathrm{~m}$. A portable climate station was installed to measure climate parameters (Table 1) in the years of the experimental period.

Experimental soils had clay-loamy texture with an available water capacity of $132.3 \mathrm{~mm}$ in $90 \mathrm{~cm}$ soil profile (Table 2). Soil $\mathrm{pH}$ values varied between 7.7 - 7.8 and salinity values varied between 0.67 $0.74 \mathrm{dS} \mathrm{m}^{-1}$. Irrigation water quality class was $\mathrm{C}_{2} \mathrm{~S}_{1}$ and suitable for use in maize culture without any problems.

Plants were irrigated with drip irrigation established with $16 \mathrm{~mm}$ lateral lines spaced $70 \mathrm{~cm}$ in rows with $4 \mathrm{~L} \mathrm{ha}^{-1}$ drippers spaced $33 \mathrm{~cm}$ apart in the rows. Double-ring infiltrometer was used to measure soil infiltration rate. The infiltration rate value for the experimental site was measured as 25 $\mathrm{mm} \mathrm{ha}^{-1}$.

Table 1. Climate parameters throughout the growing seasons.

Çizelge 1. Büyüme mevsimleri boyunca iklim parametreleri.

\begin{tabular}{|c|c|c|c|c|c|c|c|}
\hline $\begin{array}{l}\text { Year } \\
\text { Y1l }\end{array}$ & $\begin{array}{l}\text { Climate parameters } \\
\text { İklim parametreleri }\end{array}$ & $\begin{array}{l}\text { May } \\
\text { May1s }\end{array}$ & $\begin{array}{c}\text { June } \\
\text { Haziran }\end{array}$ & $\begin{array}{c}\text { July } \\
\text { Temmuz }\end{array}$ & $\begin{array}{l}\text { August } \\
\text { Ağustos }\end{array}$ & $\begin{array}{l}\text { September } \\
\text { Eylül }\end{array}$ & $\begin{array}{l}\text { October } \\
\text { Ekim }\end{array}$ \\
\hline \multirow{4}{*}{2009} & $\begin{array}{l}\text { Mean temperature }\left({ }^{\circ} \mathrm{C}\right) \\
\text { Ortalama sicaklik }\left({ }^{\circ} \mathrm{C}\right)\end{array}$ & 14.6 & 20.4 & 22.6 & 21.2 & 16.8 & 14.8 \\
\hline & $\begin{array}{l}\text { Mean relative humidity (\%) } \\
\text { Ortalama bağll nem (\%) }\end{array}$ & 59.5 & 46.9 & 49.1 & 41.6 & 55.9 & 61.1 \\
\hline & $\begin{array}{l}\text { Monthly precipitation }(\mathrm{mm}) \\
\text { Aylık yağış (mm) }\end{array}$ & 47.2 & 11.8 & 17.4 & 0.0 & 25.6 & 24.2 \\
\hline & $\begin{array}{l}\text { Wind speed }\left(\mathrm{m} \mathrm{s}^{-1}\right) \\
\text { Rüzgar hızı }\left(\mathrm{m} \mathrm{s}^{-1}\right)\end{array}$ & 0.9 & 1.1 & 1.2 & 0.9 & 0.6 & 0.7 \\
\hline \multirow{4}{*}{2010} & $\begin{array}{l}\text { Mean temperature }\left({ }^{\circ} \mathrm{C}\right) \\
\text { Ortalama sicaklik }\left({ }^{\circ} \mathrm{C}\right)\end{array}$ & 16.7 & 20.1 & 25.0 & 26.1 & 20.6 & 12.8 \\
\hline & $\begin{array}{l}\text { Mean relative humidity (\%) } \\
\text { Ortalama bağll nem (\%) }\end{array}$ & 51.2 & 58.7 & 45.8 & 38.4 & 45.8 & 68.9 \\
\hline & $\begin{array}{l}\text { Monthly precipitation }(\mathrm{mm}) \\
\text { Aylık yağ1ş }(\mathrm{mm})\end{array}$ & 35.6 & 95.2 & 7.4 & 0.5 & 0.8 & 77.8 \\
\hline & $\begin{array}{l}\text { Wind speed }\left(\mathrm{m} \mathrm{s}^{-1}\right) \\
\text { Rüzgar h1zı }\left(\mathrm{m} \mathrm{s}^{-1}\right)\end{array}$ & 1.0 & 1.3 & 1.1 & 0.9 & 1.0 & 0.8 \\
\hline
\end{tabular}

Table 2. Some physical characteristics of soil in experimental field.

Çizelge 2. Deneme alanı topraklarının bazı fiziksel özellikleri.

\begin{tabular}{|c|c|c|c|c|c|}
\hline $\begin{array}{l}\text { Depth } \\
\text { Derinlik } \\
(\mathrm{cm})\end{array}$ & $\begin{array}{l}\text { Texture } \\
\text { Tekstür }\end{array}$ & $\begin{array}{l}\text { Bulk density } \\
\text { Hacim ağırlığı } \\
\left(\mathrm{g} \mathrm{cm}^{-3}\right)\end{array}$ & $\begin{array}{l}\text { Field capacity } \\
\text { Tarla kapasitesi } \\
\left(\mathrm{cm}^{3} \mathrm{~cm}^{-3}\right)\end{array}$ & $\begin{array}{l}\text { Permanent } \\
\text { wilting point } \\
\text { Solma noktas1 } \\
\left(\mathrm{cm}^{3} \mathrm{~cm}^{-3}\right)\end{array}$ & $\begin{array}{l}\text { Available } \\
\text { water capacity } \\
\text { Faydalı su } \\
\text { kapasitesi } \\
(\mathrm{mm} / 30 \mathrm{~cm})\end{array}$ \\
\hline $0-30$ & $\mathrm{CL}$ & 1.26 & 30.6 & 15.4 & 45.6 \\
\hline $30-60$ & $\mathrm{CL}$ & 1.31 & 34.2 & 20.0 & 42.6 \\
\hline $60-90$ & $\mathrm{CL}$ & 1.32 & 36.0 & 21.3 & 44.1 \\
\hline $90-120$ & $\mathrm{CL}$ & 1.35 & 39.4 & 25.2 & 42.6 \\
\hline
\end{tabular}


Four different irrigation treatments were calculated with the use of 7-day evaporation from Class-A pan multiplied with different pan coefficients $\left(\mathrm{I}_{60}=60 \%\right.$ of pan evaporation, $\mathrm{I}_{80}=80 \%$ of pan evaporation, $\mathrm{I}_{100}=100 \%$ of pan evaporation and $\mathrm{I}_{120}=120 \%$ of pan evaporation). Experimental design was Randomized Block Design (RCBD) with three replicates. Sowing was performed at $70 \times 18 \mathrm{~cm}$ apart on plant density. Each plot $(4.2 \times 6 \mathrm{~m})$ had 6 rows. Randomized blocks were laid out $2 \mathrm{~m}$ apart and plots $3.5 \mathrm{~m}$ apart to prevent interactions.

Sowing and harvest dates were 15 May - 30 October in 2009 and 14 May - 02 November in 2010. Initial emergence was observed in the last week of May and homogeneous emergence was observed in the second week of June.

Fertilizations were performed based on soil analysis results. The plots were fertilized before planting with a compound fertilizer NPK $(15 \% \mathrm{~N}$, $\left.15 \% \mathrm{P}_{2} \mathrm{O}_{5}, 15 \% \mathrm{~K}_{2} \mathrm{O}\right)$ at the rate of 0.50 ton $\mathrm{ha}^{-1}$ in the first year, and at the rate of 0.45 ton $\mathrm{h}^{-1}$ in the second year. After planting, when the plant reached $30-40 \mathrm{~cm}$ in height, ammonium sulfate $(21 \% \mathrm{~N})$ was applied at the rate of $0.40 \mathrm{ton} \mathrm{ha}^{-1}$ in the first year, and 0.38 ton $\mathrm{ha}^{-1}$ in the second year. Pests and disease controls were practiced when needed. The ears were harvested manually. The central four rows were harvested and outer rows were omitted. One meter was also omitted from the beginning and end of each row. Therefore, harvest was performed from $11.2 \mathrm{~m}^{2}(4 \times 2.8 \mathrm{~m})$ in order to exclude boundary effects.

An initial irrigation was performed for germination and homogeneous emergence. Irrigation treatments were initiated when $30 \%$ of available water capacity was depleted (Kirda et al., 2005). Equation 1 was used to determine the amount of water to be applied as specified by Kanber (1984):

$\mathrm{I}=\mathrm{A} \times \mathrm{Epan} \times \mathrm{Kpc}$

where;

I: Applied water (liters),

Epan:7-days evaporation from class-A pan (mm),
Kpc: Crop-Pan coefficient.

$\Delta \mathrm{T}$ Profile-Probe device was used to monitor soil moisture.

Gravimetric moisture contents were used in calibration of $\Delta \mathrm{T}$ Profile-Probe. Equation 2 was used to determine crop water consumptions (ET) as recommended by James (1988):

$$
E T=I+R-D_{P}+C_{P}-R_{f} \pm \Delta S
$$

where;

ET: Crop water consumption (mm),

I: Applied water ( $\mathrm{mm})$,

$\mathrm{R}$ : Efficient precipitation ( $\mathrm{mm}$ ),

Dp: Deep percolation ( $\mathrm{mm})$,

Cp: Capillary rise $(\mathrm{mm})$,

Rf: Surface runoff ( $\mathrm{mm})$,

$\Delta \mathrm{S}$ : change in soil moisture $(\mathrm{mm})$ (calculated as the difference in moisture contents before sowing and at harvest).

Dp values were measured gravimetrically from soil samples taken from 90 and $120 \mathrm{~cm}$ depths with a soil auger before and after irrigation following the controls made with $\Delta T$ Profile-Probe. Since the experimental site was composed of deep and unsaline soils without any drainage problems, there was no capillary rise, thus $\mathrm{Cp}$ was not taken into consideration in calculations. Since the drip irrigation system was designed and operated properly, Rf was also not taken into consideration.

Equations 3 and 4 were used to determine water use efficiency (WUE) and irrigation water use efficiency (IWUE) (Tanner and Sinclair, 1983).

$W U E=\frac{E_{y}}{E T}$

where;

WUE: Water use efficiency $\left(\mathrm{kg} \mathrm{m}^{-3}\right)$,

Ey: Grain yield per hectare $\left(\mathrm{kg} \mathrm{ha}^{-1}\right)$,

ET: Seasonal crop water consumption (mm). 
$I W U E=\frac{E_{y}}{I}$

where;

IWUE: Irrigation water sue efficiency $\left(\mathrm{kg} \mathrm{m}^{-3}\right)$,

I: Seasonal irrigation water quantity $(\mathrm{mm})$.

Several models have been developed for wateryield relations. Equation 5 was used to model water-yield relations (Stewart et al., 1976).

$$
(1-Y a / Y m)=k y(1-E T a / E T m)
$$

where;

Ya: Actual grain yield per hectare under water deficit $\left(\mathrm{kg} \mathrm{ha}^{-1}\right)$,

Ym: Maximum grain yield per hectare under full irrigation $\left(\mathrm{kg} \mathrm{ha}^{-1}\right)$,

ETa: Actual crop water consumption under water deficit (mm),

ETm: Maximum crop water consumption under full irrigation $(\mathrm{mm})$,

ky: yield-response factor.

\section{Yield and yield components}

The cobs harvested from $11.2 \mathrm{~m}^{2}(4 \times 2.8 \mathrm{~m})$ were shucked and weighed. Grain moisture was measured with a grain moisture meter. Grain yield was expressed on a $15 \%$ moisture basis. To determine yield components, ten cobs from each plot were randomly selected. A hundred kernels extracted from selected cobs was randomly selected, weighed and multiplied by ten. This procedure was repeated four times and mean thousand seed weight was calculated and expressed on a $15 \%$ moisture basis. Cob diameter and length of the ten cobs were measured using a vernier caliper with an accuracy of \pm 0.01 . To determine the numbers and weight of the kernels, the kernels from the selected cobs were counted and weighed, average values were recorded.

\section{Statistical analysis}

The data were analyzed with SPSS software version 16.0 (Anonymous, 2019). The results were analyzed using analysis of variance. Differences among treatments were determined using Duncan's multiple range tests (Yurtsever, 1984; Steel and Torrie, 1980).

\section{RESULTS and DISCUSSION}

\section{Irrigation water quantity and crop water consumption}

For uniform germination and emergence, 105 and $95 \mathrm{~mm}$ irrigation water was administered in 2009 and 2010 respectively, through irrigation sprinkler. Irrigation treatments were commenced on $1^{\text {st }}$ of July and terminated on $9^{\text {th }}$ of September in 2009 and initiated on $2^{\text {nd }}$ of July and terminated on $14^{\text {th }}$ of September in 2010. Applied irrigation water quantities and water consumption are given in Table 3.

In $\mathrm{I}_{120}$, total deep percolation was calculated as 21 $\mathrm{mm}$ in 2009 and $30 \mathrm{~mm}$ in 2010. Deep percolation was not observed in $\mathrm{I}_{60}, \mathrm{I}_{80}$ and $\mathrm{I}_{100}$ treatments. Net applied irrigation water quantity varied between 431 - $676 \mathrm{~mm}$ in 2009 and 453 - $726 \mathrm{~mm}$ in 2010 . Seasonal water consumption varied between 590.1 $781.0 \mathrm{~mm}$ in 2009 and between $617.4-821.0 \mathrm{~mm}$ in 2010. The greatest water consumptions were observed in $\mathrm{I}_{120}$ treatments and the lowest in $\mathrm{I}_{60}$ treatments of both years. The present study's seasonal water consumptions at full irrigation (781 $821 \mathrm{~mm}$ ) were lower than the values of previous studies; $937 \mathrm{~mm}$ (Howell et al., 1995) and $1078 \mathrm{~mm}$ (Kuşcu et al., 2013). Such greater values were mostly obtained from the cultivation of dent corn varieties (Emeklier et al., 2018) with longer vegetative periods used in those studies. Kızıloğlu et al. (2008) reported less water consumption (688.4 $\mathrm{mm})$ than the present study for maize plants with shorter vegetative period in Erzurum compared to Konya province. 
Table 3. Applied irrigation water quantities and seasonal crop water consumptions. Çizelge 3. Uygulanan sulama suyu miktarları ve mevsimsel bitki su tüketim değerleri.

\begin{tabular}{|c|c|c|c|c|c|c|}
\hline $\begin{array}{l}\text { Year } \\
\text { Y11 }\end{array}$ & $\begin{array}{l}\text { Irrigation } \\
\text { treatments } \\
\text { Sulama } \\
\text { konuları }\end{array}$ & $\begin{array}{l}\text { Net } \\
\text { irrigation } \\
\text { water } \\
\text { Net sulama } \\
\text { suyu miktarı } \\
(\mathrm{mm})\end{array}$ & $\begin{array}{l}\text { Effective } \\
\text { rainfall } \\
\text { Etkili } \\
\text { yağ1ş } \\
\text { (mm) }\end{array}$ & $\begin{array}{l}\text { Soil moisture at } \\
\text { sowing } \\
\text { Ekimde toprak } \\
\text { nemi } \\
(\mathrm{mm} / 90 \mathrm{~cm})\end{array}$ & $\begin{array}{l}\text { Soil moisture at } \\
\text { harvest } \\
\text { Hasatta toprak } \\
\text { nemi } \\
(\mathrm{mm} / 90 \mathrm{~cm})\end{array}$ & $\begin{array}{l}\text { Seasonal } \\
\text { plant water } \\
\text { consumption } \\
\text { Mevsimlik bitki } \\
\text { su tüketimi } \\
(\mathrm{mm})\end{array}$ \\
\hline \multirow{4}{*}{2009} & $\mathrm{I}_{120}$ & 676 & 111.2 & 238.1 & 244.3 & 781.0 \\
\hline & $\mathrm{I}_{100}$ & 608 & 111.2 & 238.1 & 229.6 & 727.7 \\
\hline & $\mathrm{I}_{80}$ & 519 & 111.2 & 238.1 & 205.8 & 662.5 \\
\hline & $\mathrm{I}_{60}$ & 431 & 111.2 & 238.1 & 190.2 & 590.1 \\
\hline \multirow{4}{*}{2010} & $\mathrm{I}_{120}$ & 726 & 139.5 & 250.5 & 295.0 & 821.0 \\
\hline & $\mathrm{I}_{100}$ & 635 & 139.5 & 250.5 & 265.0 & 760.0 \\
\hline & I 80 & 544 & 139.5 & 250.5 & 236.9 & 697.1 \\
\hline & $\mathrm{I}_{60}$ & 453 & 139.5 & 250.5 & 225.6 & 617.4 \\
\hline
\end{tabular}

\section{Yield and yield components}

Kernel yields per hectare for 2009 and 2010 are provided in Table 4. Greater kernel yields obtained in 2010 than 2009 could be explained by differences in climate conditions and longer vegetative durations. There were significant differences in kernel yields per hectare of the experimental treatments $(\mathrm{p}<0.01)$.

The greatest mean kernel yield per hectare was observed in $\mathrm{I}_{100}$ irrigation in 2009 and $\mathrm{I}_{120}$ irrigation in 2010 and the least in $\mathrm{I}_{60}$ irrigations of both years. According to Duncan's test results for kernel yields, the differences between $\mathrm{I}_{120}$ and $\mathrm{I}_{100}$ irrigations were not significant. The water quantity used in $\mathrm{I}_{120}$ irrigation was $11 \%$ greater than the quantity in $\mathrm{I}_{100}$ irrigation in 2009 and $14 \%$ greater in 2010. Such findings revealed about $11-14 \%$ water savings with deficit irrigations. Previous studies also reported increased kernel yields per hectare with increased quantities of water (Kara and Biber, 2008; Payero et al., 2008; Farré and Faci, 2009). Present mean kernel yield per hectare of full irrigation treatments $\left(14480 \mathrm{~kg} \mathrm{ha}^{-1}\right)$ was greater than the values of earlier reports $(11340 \mathrm{~kg}$ ha $^{-1}$, Dağdelen et al., 2006; $10370 \mathrm{~kg} \mathrm{ha}^{-1}$, Bozkurt et al., 2011).

The relationships among yield, irrigation water and plant water consumptions are presented in Figure 1. The linear relationships among kernel yield per hectare, net irrigation water and plant water consumptions of the present study are in accordance with the results of previous research (Kurnak et al., 2003; Payero et al., 2006; Djaman et al., 2013).

Table 4. Kernel yields per hectare of experimental treatments $\left(\mathrm{kg} \mathrm{ha}^{-1}\right)$.

Çizelge 4. Konulara ait birim alan tane verimleri $\left(\mathrm{kg} \mathrm{ha}^{-1}\right)$.

\begin{tabular}{lccc}
\hline Treatments (I) & \multicolumn{2}{c}{ Year $(\mathrm{Y}) /$ Y1l $(\mathrm{Y})$} & Mean \\
\cline { 2 - 4 } Konular (I) & 2009 & 2010 & Ortalama \\
\hline $\mathrm{I}_{120}$ & $13187 \mathrm{a}$ & $15773 \mathrm{a}$ & $14480 \mathrm{a}$ \\
$\mathrm{I}_{100}$ & $13188 \mathrm{a}$ & $15160 \mathrm{a}$ & $14174 \mathrm{a}$ \\
$\mathrm{I}_{80}$ & $9575 \mathrm{~b}$ & $11920 \mathrm{~b}$ & $10748 \mathrm{~b}$ \\
$\mathrm{I} 60$ & $8986 \mathrm{~b}$ & $10527 \mathrm{c}$ & $9757 \mathrm{~b}$ \\
\hline $\mathrm{I}$ & ${ }^{* *}$ & ${ }^{* *}$ & ${ }^{* *}$ \\
\hline $\mathrm{I} \times \mathrm{Y}$ & & & ${ }^{*}$ \\
\hline $\mathrm{CV}(\%)$ & 6.67 & 2.93 & 4.86
\end{tabular}

${ }^{* * *} \mathrm{p}<0,01,{ }^{*} \mathrm{p}<0,05$, ns: not significant (önemli değil). Same letters in a column are not significantly different at the 0.01 probability levels [Aynı harfle gösterilen ortalamalar arasında önemli fark $(\mathrm{P} \leq 0,01)$ yoktur]. 


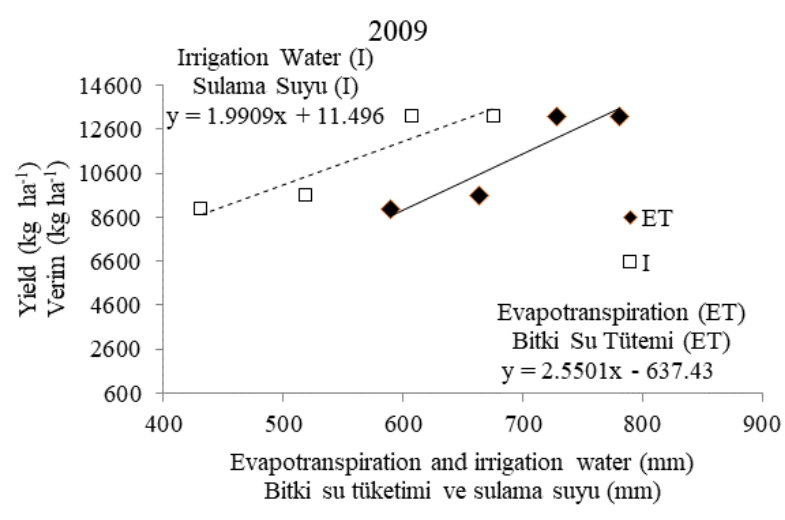

2010

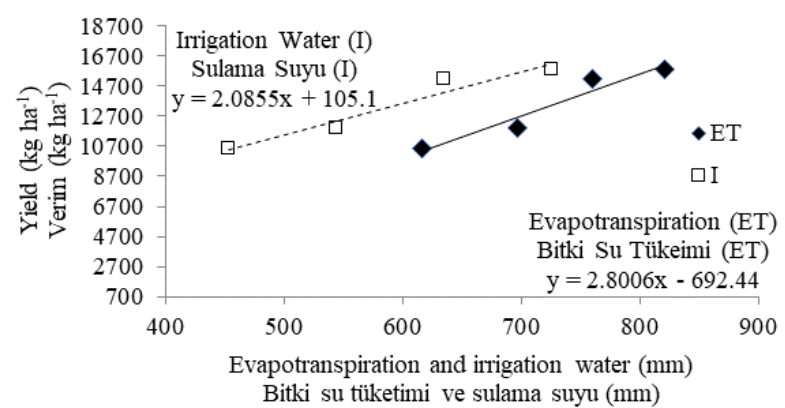

Figure 1. Relationships among yield, irrigation water and plant water consumptions.

Şekil 1. Verim, sulama suyu ve bitki su tüketimi arasındaki ilişkiler.

The maize yield components of the present experimental treatments (different irrigation regimes) are provided in Table 5. Differences in thousand-kernel weight, cob length and diameter, number of kernels per cob and kernel weight per cob of the experimental treatments were found to be significant. Only the differences in number of kernels per cob were not significant in 2009.

Yield components were positively affected by irrigation treatments and increasing values were observed with increasing amount of water. According to Duncan's test results for yield components, $\mathrm{I}_{120}$ and $\mathrm{I}_{100}$ treatments were generally found in the same group in both years. It can be concluded that the irrigation amount difference between the $I_{120}$ and $I_{100}$ treatment did not significantly affect yield components. Özgürel and
Pamuk (2003) reported the least thousand-kernel weights $(265-271 \mathrm{~g})$ in deficit irrigations and the greatest values $(332-353 \mathrm{~g})$ in full irrigations indicating significant decreases in thousand-kernel weights with water deficits. Vural and Dağdelen (2008) reported significant effects of irrigations on thousand-kernel weight of maize. Gençel (2002) reported thousand-kernel weights under different irrigation regimes as between 328.7 - $353.2 \mathrm{~g}$ with the greatest value from full irrigation.

Vural and Dağdelen (2008) reported significant effects of irrigation treatments on cob diameters. İstanbulluoğlu and Kocaman (1996) indicated that water deficits at the tasseling formation stage prevented pollination and thus reduced number of kernels. In present study, number of kernels per cob also decreased with water deficits. Çakır (2004) indicated that water deficits at full mature stage reduced kernel weights; İstanbulluoğlu and Kocaman (1996) reported average cob lengths as between 16.7 - $20.4 \mathrm{~cm}$ and Özgürel and Pamuk (2003) as between $13.7-20.0 \mathrm{~cm}$. Present cob lengths are in accordance with those earlier studies.

\section{Water use efficiencies}

The ratio of biomass or kernel yield to water used to produce this biomass is defined as water use efficiency while the ratio of yield to irrigation water supplied is defined as irrigation water use efficiency. WUE indicates the amount of production per unit of water. Apart from applied water, plants also benefit from soil moisture and precipitation. Plants also may not be able to fully benefit from irrigation water since there may be runoff and deep percolation. Water and irrigation water use efficiencies both generally affected by yield potential, method of irrigation, environmental and climatic parameters (Kuşcu et al., 2013). In the present study, soil, climate and agronomic practices had different effects on WUE and IWUE values, therefore differences were observed in both values (Table 6). 

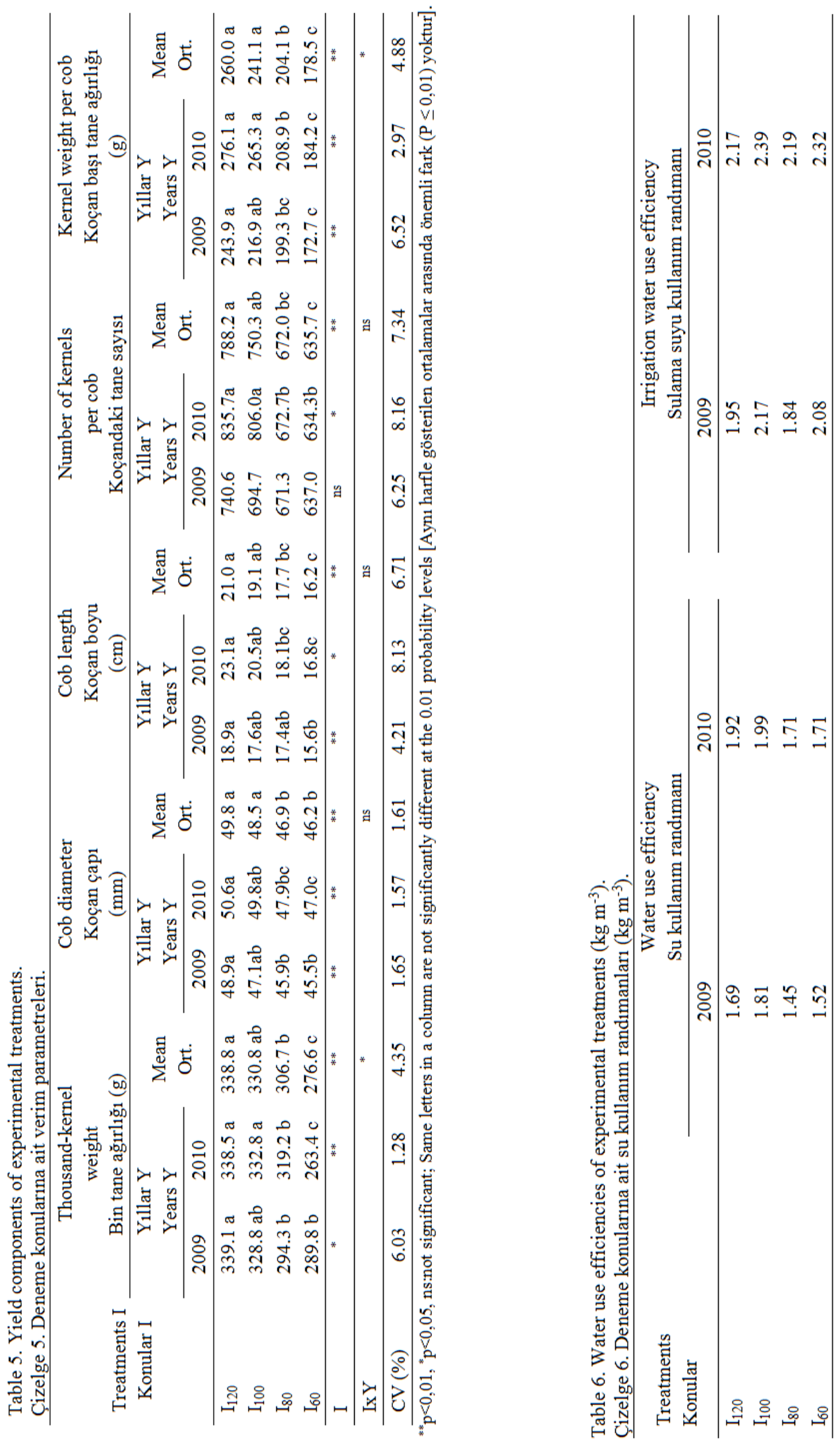
Water use efficiency (WUE) of $\mathrm{I}_{120}, \mathrm{I}_{100}, \mathrm{I}_{80}$ and $\mathrm{I}_{60}$ irrigation were determined to be $1.69,1.81,1.45$ and $1.52 \mathrm{~kg} \mathrm{~m}^{-3}$ in 2009 and as $1.92,1.99,1.71$ and $1.71 \mathrm{~kg} \mathrm{~m}^{-3}$ in 2010 , respectively. Irrigation water use efficiency (IWUE) of $\mathrm{I}_{120}, \mathrm{I}_{100}, \mathrm{I}_{80}$ and $\mathrm{I}_{60}$ irrigations were determined to be $1.95,2.17,1.84$ and $2.08 \mathrm{~kg} \mathrm{~m}^{-3}$ in 2009 and as $2.17,2.39,2.19$ and $2.32 \mathrm{~kg} \mathrm{~m}^{-3}$ in 2010, respectively. The greatest WUE and IWUE were obtained from $\mathrm{I}_{100}$ treatments and the least from $\mathrm{I}_{80}$ treatments in both years. When the water and irrigation water use efficiencies of $\mathrm{I}_{120}$ and $\mathrm{I}_{100}$ irrigations with the greatest yields were compared, it was observed that in both years, $\mathrm{I}_{100}$ treatments had greater WUE (1.81-1.99) and IWUE (2.17-2.39) values than the $\mathrm{I}_{120}$ treatments WUE (1.69-1.92) and IWUE (1.952.17). These findings suggest that that greatest yields per unit of water were achieved in $I_{100}$ treatments, thus full irrigation was recommended for maize irrigation in Konya province.

WUE values were lower than IWUE values in both years since plants benefited from already available stored water within the soil profile before the growing season and plant water consumptions varied based on available water capacity of the soils. Present WUE (1.81-1.92) and IWUE (2.172.17) values of the treatments with the largest yields were greater than the values of Kuşcu et al. (2013) (WUE: 1.52-1.58; IWUE: 1.24-1.02); Abd El- Wahed and Ali (2013) (WUE: 1.21-1.22). In those studies, it was observed that less water was consumed per kg maize production in Konya Plain with shorter vegetative durations. Yazar et al. (2002) conducted a study in Harran Plain on second crop maize with shorter vegetative duration and reported WUE values of the treatment with the greatest yields as 2.01 and 2.11 and IWUE values as 1.95 and 2.05 .

\section{Yield-response factor (ky)}

The ky designates the relative effects of deficit irrigations on yields. A ky value greater than 1 indicates plant sensitivity to deficit irrigations and a ky value less than 1 indicates plant tolerance to water deficit (Steduto et al., 2012).

The relative decreases in yield corresponding to the relative decreases in water consumption for 2009 are provided in Table 7. As can be inferred from the Table, in 2009, the highest yield was not observed in treatments with the greatest seasonal water consumption. The method specified by Köksal et al. (2001) was used while calculating yield-response in 2009. While calculating ky values, the relationships between actual water consumptions and yields were investigated through regression analysis and a linear relationship was determined between water consumptions and yields. With the use of the equation of this linear relationship, a new yield value was calculated for the treatment with the largest water consumption. The ky graphs and relevant regression equations are presented in Figure 2. A linear relationship was observed between water consumption and yields, and yields increased with increasing water consumption.

Relative decreases in yield corresponding to relative decrease in water consumption for 2010 are provided in Table 8 . The resultant regression equations and ky graphs are shown in Figure 2.

Table 7. Relative decrease in yield corresponding to relative decrease in water consumption in 2009.

Çizelge 7. 2009 yılına ait oransal su tüketimi açığına karşılık oransal verim azalması değerleri.

\begin{tabular}{|c|c|c|c|c|c|c|}
\hline $\begin{array}{l}\text { Treatments } \\
\text { Konular }\end{array}$ & $\operatorname{ETm}(\mathrm{mm})$ & $\mathrm{ETa}(\mathrm{mm})$ & 1-ETa/ETm & Ym $\left(\mathrm{kg} \mathrm{ha}^{-1}\right)$ & Ya $\left(\mathrm{kg} \mathrm{ha}^{-1}\right)$ & $1-\mathrm{Ya} / \mathrm{Ym}$ \\
\hline $\mathrm{I}_{120}$ & 781 & - & 0.00 & $13542^{*}$ & 13187 & 0.00 \\
\hline $\mathrm{I}_{100}$ & - & 728 & 0.07 & 13188 & - & 0.03 \\
\hline $\mathrm{I}_{80}$ & - & 663 & 0.15 & - & 9576 & 0.29 \\
\hline $\mathrm{I}_{60}$ & - & 590 & 0.24 & - & 8986 & 0.34 \\
\hline
\end{tabular}

${ }^{*} \mathrm{Ym}$ is adjusted maximum yield with the equation of 2.5501ET-637.43 (Köksal et al., 2001).

*Ym: 2,5501ET-637,43 denklemiyle hesaplanan düzeltilmiș en yüksek verim değeri. (Köksal ve ark., 2001).

ETm: Maximum crop water consumption under full irrigation $(\mathrm{mm}) / \mathrm{ETm}$ : Tam sulama şartlarında en yüksek bitki su tüketimi (mm).

ETa: Actual crop water consumption under water deficit $(\mathrm{mm}) / \mathrm{ETa}$ : Kısıtll sulama şartları altında gerçekleşen bitki su tüketimi (mm).

Ym: Maximum grain yield per hectare under full irrigation $\left(\mathrm{kg} \mathrm{ha}^{-1}\right) / \mathrm{Ym}$ : Tam sulama şartlarında en yüksek verim $\left(\mathrm{kg} \mathrm{ha}^{-1}\right)$.

Ya: Actual grain yield per hectare under water deficit $\left(\mathrm{kg} \mathrm{ha}^{-1}\right) / \mathrm{Ya}$ Kısıtlı sulama şartlarında gerçekleşen verim $\left(\mathrm{kg} \mathrm{ha}^{-1}\right)$. 

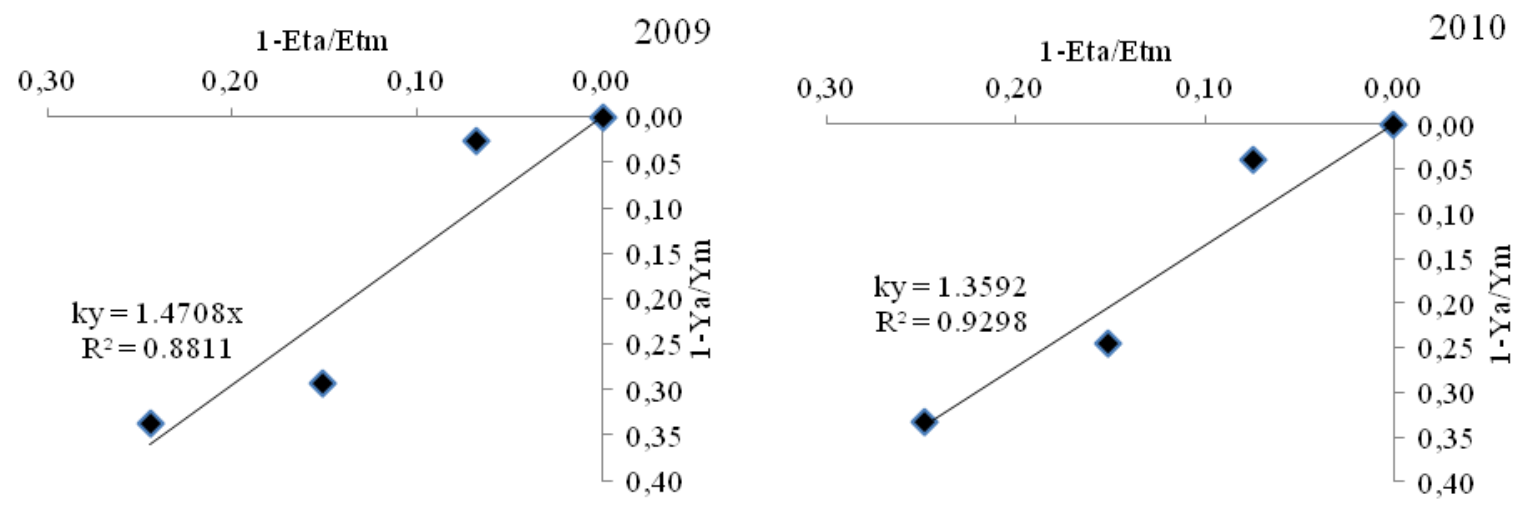

Figure 2. Relationships between relative decrease in water consumptions and relative decrease in yields in 2009 and 2010. Şekil 2. 2009-2010 yılları mısır bitkisi oransal su tüketim açı̆̆ı ile oransal verim azalışı ilişkisi.

ETm: Maximum crop water consumption under full irrigation $(\mathrm{mm})$ / ETm: Tam sulama şartlarında en yüksek bitki su tüketimi (mm).

ETa: Actual crop water consumption under water deficit $(\mathrm{mm}) / \mathrm{ETa}$ : Kısıtlı sulama şartları altında gerçekleșen bitki su tüketimi.

$\mathrm{Ym}$ : Maximum grain yield per hectare under full irrigation $\left(\mathrm{kg} \mathrm{ha}^{-1}\right) / \mathrm{Ym}$ : Tam sulama şartlarında en yüksek verim $\left(\mathrm{kg} \mathrm{ha}^{-1}\right)$.

Ya: Actual grain yield per hectare under water deficit $\left(\mathrm{kg} \mathrm{ha}^{-1}\right) /$ Ya: Kısıtlı sulama şartlarında gerçekleşen verim $\left(\mathrm{kg} \mathrm{ha}^{-1}\right)$.

Table 8. Relative decrease in yield corresponding to relative decrease in water consumption in 2010.

Çizelge 8. 2010 yılına ait oransal su tüketimi açığına karşılık oransal verim azalması değerleri.

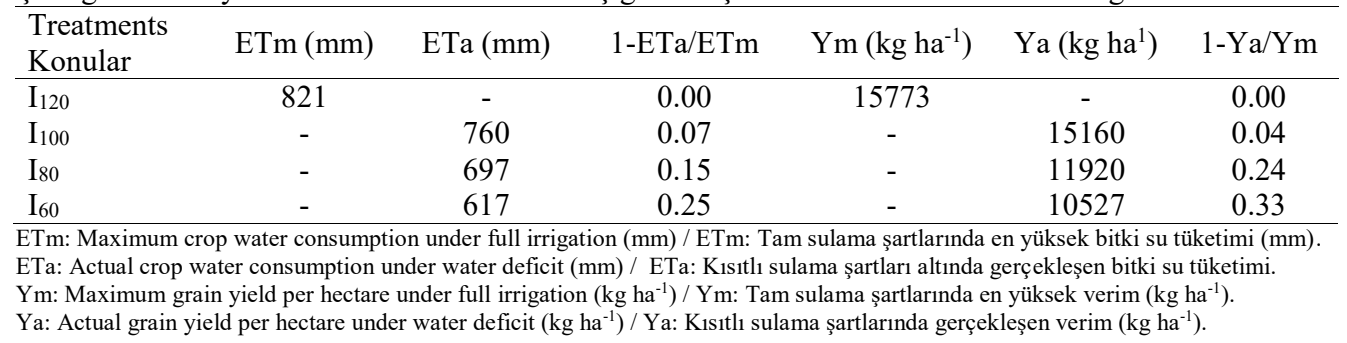

Again, a linear relationship was obtained between water consumption and yield. The ky of maize was calculated as 1.47 in 2009 and 1.36 in 2010. Doorenbos and Kassam (1979) indicated that seasonal ky of maize could be taken as 1.25 . The present study's yield response factors were similar with the values reported by Kızıloğlu et al. (2008) (1.51) and Payero et al. (2009) (1.50), but greater than the values of several other researchers (Karam et al., 2003; Öktem, 2008; Kuşcu et al., 2013).

\section{CONCLUSION}

Water-yield relations of maize were investigated in this study. Kernel yields per hectare decreased with water stress. There were linear relationships among yield, net irrigation water and plant water consumption. In both years, WUE values varied between $1.45-1.99 \mathrm{~kg} \mathrm{~m}^{-3}$ and IWUE values varied between $1.84-2.39 \mathrm{~kg} \mathrm{~m}^{-3}$. In both years, the greatest water and irrigation water use efficiencies were observed in $\mathrm{I}_{100}$ and the least in $\mathrm{I}_{80}$ treatments. The ky of maize was calculated as 1.47 in 2009 and 1.36 in 2010. These values could be used in maize culture of arid and semi-arid regions. Full irrigation $\left(I_{100}\right)$ was identified as the ideal irrigation program. Despite the greatest yield of $\mathrm{I}_{100}$ irrigation, $\mathrm{I}_{80}$ also had a yield quite close to average yields of Turkey and Konya province. Therefore, it was concluded that $\mathrm{I}_{80}$ treatments could be used in Konya Plain and similar ecosystems.

\section{ACKNOWLEDGEMENTS}

This study was derived from Master Thesis "Water-yield relations of corn plant irrigated with drip irrigation in Konya ecological conditions" of Süheyla Kara. 


\section{REFERENCES}

Abd El-Wahed, M. H., and E. A. Ali. 2013. Effect of irrigation systems, amounts of irrigation water and mulching on corn yield, water use efficiency and net profit. Agricultural Water Management 120: 64-71. https://doi.org/10.1016/j.agwat.2012.06.017

Anonymous. 2017. Turkish Grain Board Report. http://www. tmo.gov.tr/Upload/Document/hububat/HububatRaporu 2017.pdf (accessed May 2019).

Anonymous. 2018. Turkey Statistical Institute. https://biruni tuik.gov.tr $/$ medas $/$ ?kn=92\&locale $=\operatorname{tr} \quad$ (accessed April 2019).

Anonymous. 2019. SPSS 16.0. Statistical software of IBM.

Bozkurt, S., A. Yazar, and G. S. Mansuroglu. 2011. Effects of different drip irrigation levels on yield and some agronomic characteristics of raised bed planted corn. African Journal of Agriculture Research 6 (23): 52915300. https://doi.org/10.5897/AJAR11.232.

Cakır, R. 2004. Effect of water stress at different development stages on vegetative and reproductive growth of corn. Field Crops Research 89: 1-16. https://doi.org/10. 1016/j.fcr.2004.01.005.

Dağdelen, N., E. Y1lmaz, F. Sezgin, and T. Gurbuz. 2006. Wateryield relation and water use efficiency of cotton (Gossypium hirsutum L.) and second crop corn (Zea mays L.) in western Turkey. Agricultural Water Management 82: 63-85. https://doi.org/10.1016/ j.agwat.2005.05.006.

Doğan, E., and H. Kırnak. 2010. Water temperature and system pressure effect on drip lateral properties. Irrigation Science 28: 407-419. https://doi.org/10. 1007/s00271-009-0202-Z.

Doorenbos, J., and A. H. Kassam. 1979. Yield response to water. FAO Irrigation Drainage. Paper no. 33. United Nations Food and Agriculture Organization, Rome, Italy.

Djaman K., S. Irmak, W. R. Rathje, D. L. Martin, and D. E. Eisenhauer. 2013. Maize evapotranspiration, yield production function, biomass, grain yield, harvest index, and yield response factors under full and limited irrigation. Transactions of the ASAE 56 (2): 273-293. https://doi.org/10.13031/2013.42676.

Emeklier, H. Y. 2018. Tarla Bitkileri (Sicak İklim Tahılları). Ankara Üniversitesi, Ziraat Fakültesi Yayınları Ders K. No: 594 s.199-270, Ankara.

Farré, I., and J. M. Faci. 2009. Deficit Irrigation in maize for reducing agricultural water use in a Mediterranean environment. Agricultural Water Management 96: 383-394. https://doi.org/10.1016/j.agwat.2008.07.002.

Howell, T. A., A. Yazar, A. D. Schneider, D. A. Dusek, and K. S. Copeland. 1995. Yield and Water Use Efficiency of Corn in Response to LEPA Irrigation. Transactions of the ASAE 38 (6): 1737-1747. https://doi.org/10. 13031/2013.28001.
Gençel, B. 2002. GAP (Güneydoğu Anadolu Projesi) Bölgesinde ikinci ürün misır bitkisinin damla yöntemiyle sulanması üzerinde bir çalışma. University of Cukurova, Department of Agricultural Structures and Irrigation Institute of Natural and Applied Sciences Master Thesis, 61s. Adana, Turkey.

Irmak, S., D. Z. Haman, and J. W. Jones. 2002. Evaluation of Class A pan coefficients for estimating reference evapotranspiration in humid location. Journal of Irrigation and Drainage Engineering 128 (3): 153-159. https://doi.org/10.1061/(ASCE)0733-9437

İstanbulluoğlu, A. ve İ. Kocaman. 1996. Tekirdağ koşullarında mısırın su-verim ilişkileri. Journal of Tekirdağ Agricultural Faculty. General Publication Number 251, Research publication number: 97, Tekirdağ, Türkiye.

James, L. G. 1988. Principles of farm irrigation system design. Wiley, New York.

Kanber, R. 1984. Çukurova koşullarında açık su yüzeyi buharlaşmasında (Class A Pan) yararlanarak birinci ve ikinci ürün yer fistığının sulanması. Topraksu Araştırma Enstitüsü Müdürlüğü Yayınları Genel Yayın No: 114, Türkiye.

Kara, T., and C. Biber. 2008. Irrigation frequencies and corn (Zea mays L.) yield relation in Northern Turkey. Pakistan Journal of Biological Sciences 11 (1): 123126.

Karam, F., J. Breidy, C. Stephan, and J. Rouphael. 2003. Evapotranspiration, yield and water use efficiency of drip irrigated corn in the Bekaa Valley of Lebanon. Agricultural Water Management 63 (2): 125-137. https://doi.org/10.1016/S0378-3774(03)00179-3

Kurda, C. 2002. Deficit irrigation scheduling based on plant growth stages showing water stress tolerance. In: Deficit irrigation practice. Water reports 22. pp. 1-3. FAO, Rome,

Kırda, C., S. Topcu, H. Kaman, A. C. Ulger, A. Yazıcı, M. Çetin, and M. R. Derici. 2005. Grain yield response and $\mathrm{N}$-fertilizer recovery of maize under deficit irrigation. Field Crop Research 93: 132-141. https://doi.org/10.1016/j.fcr.2004.09.015.

Kırnak, H., C. Gençoğlan, and V. Değirmenci. 2003. Effect of deficit irrigation on yield and growth of second crop corn in Harran plain conditions. Atatürk Üniversity Journal of Agricultural Faculty 34 (2): 117-123.

Kızıloğlu, F. M., U. Şahin, Y. Kuşlu, and T. Tunç. 2008. Determining water-yield relationship, water use efficiency, crop and pan coefficients for silage maize in a semiarid region. Irrigation Science 27: 129-137. https://doi.org/10.1007/s00271-008-0127-y.

Köksal, H., A. Tarı, R. Çakır, R. Kanber, and M. Ünlü. 2001. Water-yield relationships. Rural Services Research Main Project 435 (1): 87, Türkiye.

Kuşcu, H., A. Karasu, M. Oz, A. O, Demir, and İ. Turgut. 2013. Effect of irrigation amounts applied with drip 
irrigation on maize evapotranspiration, yield, water use efficiency and net return in a sub-humid climate. Turkish Journal of Field Crops 18 (1): 13-19.

Öktem, A. 2008. Effect of water shortage on yield, and protein and mineral compositions of drip-irrigated sweet corn in sustainable agricultural systems. Agricultural Water Management 95: 1003-1010. https://doi.org/10.1016/ j.agwat.2008.03.006.

Özgürel, M. ve G. Pamuk. 2003. Misır bitkisinin su-verim ilişkileri ve CERES-maize bitki büyüme modelinin bölge koşullarına uygunluğunun irdelenmesi üzerine bir araştırma. TÜBITAK-TARP-2340, Türkiye.

Payero, J. O., S. R. Melvin, S. Irmak, and D. D. Tarkalson. 2006. Yield response of corn to deficit irrigation in a semiarid climate. Agricultural Water Management 84: 101-112. https://doi.org/10.1016/j.agwat.2006.01.009.

Payero, J. O., D. D. Tarkalson, S. Irmak, D. Davison, and J. L. Petersen. 2008. Effect of irrigation amounts applied with subsurface drip irrigation on corn evapotranspiration, yield, water use efficiency, and dry matter production in a semiarid climate. Agricultural Water Management 95: 895-908. https://doi.org/ 10.1016/ j.agwat.2008.02.015.

Payero J. O., D. D. Tarkalson, S. Irmak, D. Davison, and J. L. Petersen. 2009. Effect of timing of a deficit-irrigation allocation on corn evapotranspiration, yield, water use efficiency and dry mass. Agricultural Water Management 96:1387-1397. https://doi.org/10.1016/ j.agwat.2009.03.022.

Steel, R. G., D., and J. H. Torrie. 1980. Principles and Procedures of Statistics. Second Ed. McGraw-Hill Book Company Inc., New York.
Steduto, P., T. C. Hsiao, E. Fereres, and D. Raes. 2012. Crop yield response to water. Vol. 1028, United Nations Food and Agriculture Organization, Rome, Italy.

Stewart, J. I., R. M. Hagan, and W. O. Pruitt. 1976. Production functions and predicted irrigation programs for principal crops as required for water resources planning and increased water use efficiency. Technical Bureau Recl. No: 14- 06-D. 7329, USA, p. 80.

Tanner, C. B., and T. R. Sinclair. 1983. Efficient water use in crop production: Research or re-search? (Eds. H.M.Taylor et al.). Limitations to Efficient Water Use in Crop Production. American Society Apron. Inc. 127 https://doi.org/10.2134/1983.limitationsto efficient wateruse.c1.

Van Donk, S. J., J. L. Petersen, and D. R. Davison. 2013. Effect of amount and timing of subsurface drip irrigation on corn yield. Irrigation Science 31: 599609.

Vural, Ç., and N. Dağdelen. 2008. Effects of different irrigation scheduling on yield and some agronomic characteristics of drip irrigated popcorn. Journal of Adnan Menderes University Agricultural Faculty 5 (2): $97-104$.

Yazar, A., S. M. Sezen, and B. Gencel. 2002. Drip irrigation of corn in the Southeast Anatolia Project (GAP) area in Turkey. Irrigation and Drainage 51: 293-300. https://doi.org/10.1002/ird.63.

Yurtsever, N. 1984. Deneysel İstatistik Metotları. Köy Hizmetleri Toprak ve Gübre Arş. Enst. Müdürlüğü Yayınları Genel Yayın No. 121 Ankara. 